\title{
Collective ResponsibiLITY AND THE LIMITS OF DISCLOSURE IN REGULATING Global SUPPLy Chains
}

\section{Charlotte Villiers*}

Global supply chains present major challenges for company law and corporate governance, nationally and internationally. Their increasing relevance in international business has led to a serious regulatory gap, especially in light of corporate involvement in human rights abuses, labour exploitation and environmental degradation. Alongside a number of international norms such as those expressed in the UN's Guiding Principles on Business and Human Rights, there has been a proliferation in domestic and international law of disclosure provisions, mandating greater transparency by companies in response to the problems caused by global supply chains. In this paper, however, it is argued that disclosure is not a sufficient answer to such problems. It is suggested that we should approach the problems with a different conceptualisation of supply chain structures. If we regard them as 'global poverty chains', such a perspective brings about a moral response - a recognition that we have a collective responsibility to eradicate the poverty and suffering caused by the chains. This response necessitates that transparency requirements be altered and accompanied by a regulatory framework that empowers victims of poverty to be able to escape it.

\section{INTRODUCTION}

Global supply chains present major challenges for company law and corporate governance, nationally and internationally. Their increasing relevance in international business has led to a regulatory gap - the failure of government to provide mechanisms to prevent corporate involvement in human rights abuses, labour exploitation and environmental degradation. This article evaluates the transparency measures — in the form of 'hard' and 'soft',

\footnotetext{
* Professor of Company Law and Corporate Governance, University of Bristol. Many thanks to Nina Boeger, Roseanne Russell and participants at the ICGL Forum in Hamburg, 2017, for their comments on earlier versions of this article. Remaining errors are mine alone.
} 
mandatory and voluntary, national and international disclosure provisions that have appeared as a leading regulatory response to the challenges presented by supply chains. Their proliferation is possibly explained by the fact that mandated disclosure is easier to introduce than more 'direct and intrusive' measures. ${ }^{1}$

The structural complexity of supply chains presents obstacles to an effective disclosure system. Within such organisational complexity, which remains largely unquestioned, to whom are the disclosures to be made and who is to hold any misbehaving supply chain actors to account? I suggest, following Ben Selwyn, ${ }^{2}$ that we must adopt a different conceptualisation of these business structures; we must see them as global poverty chains, in which the lead companies earn vast profits and global inequality rises, resulting in an 'immiserated' labour force in the global south (or developing countries) and an undermined and threatened labour force in the global north (or developed countries). ${ }^{3}$ This conceptualisation inspires a moral response to the processes that cause or contribute to human rights abuses and global inequality, and underlines the fact that we have a collective responsibility to eradicate the poverty and suffering caused by the supply, or poverty, chains. The disclosure requirements must then be developed into a regulatory framework that empowers those impoverished by them. Those who are privileged at the expense of the poor have a duty to end that poverty in a way that emancipates the exploited participants. Transparency should be part of a system that enables stakeholders to hold companies to account and to act together to end the structural injustices and to work genuinely to end the poverty and human suffering that blights so many regions of the world in the name of profit and economic growth. This requires a multi-dimensional but cohesive international legal and regulatory system rather than a fragmented collection of demands for information.

This article proceeds by looking at the structural complexities found in supply chains. It identifies their negative impacts, concentrating especially on labour

\footnotetext{
${ }^{1}$ Adam S Chilton and Galit A Sarfaty, 'The Limitations of Supply Chain Disclosure Regimes' (2017) 53 Stanford Journal of International Law 1, 21, citing Omri Ben-Shahar and Carl Schneider, More Than You Wanted to Know: The Failure of Mandated Disclosure (Princeton University Press, 2014) 4.

${ }^{2}$ Benjamin Selwyn, 'Global Value Chains or Global Poverty Chains? A New Research Agenda' (Working Paper No 10, University of Sussex, Centre for Global Political Economy, June 2016) $2<$ http://www.sussex.ac.uk/cgpe/research/workingpapers>. See also Benjamin Selwyn, 'Social Upgrading and Labour in Global Production Networks: A Critique and an Alternative Conception' (2013) 17 Competition and Change 75.

${ }^{3}$ Arguably, Australia would be placed into the global north category as a developed country, for the purposes of this discussion.
} 
exploitation and human rights abuses. It then examines the regulatory approach typical in neoliberal corporate governance regimes - the requirement of transparency - and demonstrates that transparency measures have not succeeded in solving the problems. Finally, it develops Selwyn's reconceptualisation of these chains as global poverty chains and suggests a different regulatory response.

\section{The Structural Complexities of Supply Chains}

Global value chains are an established and widely used production arrangement and they are used in many industries, including manufacturing, the energy industry, the agri-food industry, and a myriad of financial and business services. ${ }^{4}$ They are characterised by an 'international fragmentation of production'.5 The integrated components of design, production and retail, spread across either a few or thousands of firms, constitute the product or service. ${ }^{6}$ Since 2011, global value chain trade has accounted for $60-67$ per cent of global trade in value-added terms. ${ }^{7}$ The United Nations Conference on Trade Development (UNCTAD) in its World Investment Report suggested that global value chains shaped by transnational corporations 'account for some $80 \%$ of global trade ${ }^{8}$ and the ILO has estimated that more than 450 million people work in supply chain-related jobs. ${ }^{9}$

Global value chains spread themselves across geographic boundaries and across different legal systems and jurisdictions, leading the Institute for Global Law and Policy Working Group ${ }^{10}$ to observe that 'mapping GVCs from a legal

${ }^{4}$ Michael Rawling, 'Legislative Regulation of Global Value Chains to Protect Workers: A Preliminary Assessment' (2015) 26 The Economic and Labour Relations Review 660, 663.

5 OECD, WTO and UNCTAD, Implications of Global Value Chains for Trade, Investment, Development and Jobs. Prepared for the G-20 Leaders Summit, Saint Petersburg (Russian Federation) (6 August 2013) $11<\mathrm{http} / /$ unctad.org/en/pages/PublicationWebflyer.aspx? publicationid $=643>$.

6 Kevin B Sobel-Read, 'Global Value Chains: A Framework for Analysis' (2014) 5 Transnational Legal Theory 364, 369.

${ }^{7}$ WTO and others, Global Value Chain Development Report 2017: Measuring and Analysing the Impact of GVCs on Economic Development (September 2017) $2<\mathrm{https} / / / \mathrm{www}$.wto. org/english/res_e/publications_e/gved_report_17_e.htm>.

${ }^{8}$ OECD, WTO and UNCTAD, above n 5, 21.

${ }^{9}$ International Labour Organization, 'Forced Labour, Human Trafficking and Slavery' (undated) $<$ http://www.ilo.org/global/topics/forced-labour/lang--en/index.htm>.

${ }^{10}$ The Institute for Global Law and Policy (IGLP) is based at Harvard Law School and has the goal of nurturing innovative approaches to global policy. This Law and Global production Working Group's mapping exercise is a project of the Institute and forms part of the work 
perspective ... poses complex challenges for basic questions of positive legal analysis, including matters of territorial jurisdiction, governing law, private regulation through contract and sovereign authority'. ${ }^{11}$ One consequence of their global reach is that global value chains have given rise to regulatory and governance gaps, allowing them to be conduits for profit, but at the expense of environmental damage, labour exploitation and human rights abuse.

A major cause of the regulatory gap is the complexity of these chains. Not being strictly linear, they have, to change the metaphor [since chains cannot have tiers], multiple tiers and they have horizontal, vertical and spatial complexities that interact and lead to uncertainties, production disruptions ${ }^{12}$ and regulatory challenges. The fragmented nature of the production processes leads many chains to require multiple layers of suppliers. Often, companies may be able to locate their first-tier suppliers, but the suppliers in the lower tiers may be less easy to identify. ${ }^{13}$ Sarfaty reveals that one company required more than a year to map its supply chain, ${ }^{14}$ and quotes an employee of the technology company, Philips, explaining that, 'for electronic components, the supply chain can easily be 50 tiers deep, many of which may provide us with limited or no information' ${ }^{15}$ In 2015, Clarke and Boersma reported that Apple had 785 suppliers in 31 countries worldwide contributing to the production of the iPhone. ${ }^{16}$ Some commentators identify different types of complexity: static complexity - the structure of the supply chain, the number and the variety of its components and the strength of the interactions between these components;

within the project on Corporate Power in Global Society: Explication, Critique, Engagement, and Resistance. See further at $<$ http://iglp.law.harvard.edu/research-agenda-and-history/>.

${ }^{11}$ The IGLP Law and Global Production Working Group, 'The Role of Law in Global Value Chains: A Research Manifesto' (2016) 4 London Review of International Law 57, 61-2.

${ }^{12}$ Christoph Bode and Stephan M Wagner, 'Structural Drivers of Upstream Supply Chain Complexity and the Frequency of Supply Chain Disruptions' (2015) 36 Journal of Operations Management 215.

${ }^{13}$ Galit A Sarfaty, 'Shining Light on Global Supply Chains' (2015) 56 Harvard International Law Journal 419, 431.

${ }^{14}$ Shift Project, 'Respecting Human Rights through Global Supply Chains, 7 (2012) cited in Sarfaty, above n 13, 432.

${ }^{15}$ Ibid 431.

${ }^{16}$ Thomas Clarke and Martijn Boersma, 'The Governance of Global Value Chains: Unresolved Human Rights, Environmental and Ethical Dilemmas in the Apple Supply Chain' (2017) 143 Journal of Business Ethics 111, 115. 
and dynamic complexity - the uncertainty in the supply chain on aspects of production time and supply chain relations. ${ }^{17}$

Global value chains have fluid arrangements and they lack predictability, making them vulnerable to political instability, technological changes, and new legal requirements. Such changing conditions give to them a dynamic nature, but maintaining updated lists of suppliers and sub-suppliers becomes difficult. Indeed, some suppliers, as a result of competition pressures or fluctuations in the price or range of goods, further subcontract parts of their production to other firms that are not directly linked to the buyer and which may include smaller companies, informal workshops and home-based workers who will work informally and remain unknown to the lead firm. ${ }^{18}$ Thus, while multinational corporations (MNCs) might be incorporated and headquartered in a particular jurisdiction, many of their economic activities occur abroad in areas that are beyond the regulatory reach of their home jurisdiction, or they may operate in developing countries which do not have sufficient resources or structures for effective regulation. ${ }^{19}$ As Chilton and Sarfaty observe, where host states lack the political capacity, the rule of law, and/or the will to enforce human rights norms and provide redress to victims of human rights violations, such regulatory gaps open up. ${ }^{20}$ Those host states are primarily concerned with attracting foreign investment, leading them to overlook domestic law violations or to hold off on passing human rights regulations, fearing that companies might shift their business elsewhere to avoid regulatory burdens. ${ }^{21}$ Global value chains have the opportunity for regulatory arbitrage, giving rise to governance

\footnotetext{
${ }^{17}$ Seyda Serdarasan, 'A Review of Supply Chain Complexity Drivers' (2013) 66 Computers and Industrial Engineering 533. See also Sam Sarpong, 'Traceability and Supply Chain Complexity: Confronting the Issues and Concerns' (2014) 26 European Business Review 271.

${ }^{18}$ Peter Lund-Thomsen et al, 'Labour in Global Value Chains: Work Conditions in Football Manufacturing in China, India and Pakistan' (2012) 43 Development and Change 1211, cited in International Labour Office, Decent Work in Global Supply Chains, Report IV, International Labour Conference, 105 ${ }^{\text {th }}$ Session 2016 (2016) $7<$ http://www.ilo.org/ilc/ILCSessions/ 105/reports/reports-to-the-conference/WCMS_468097/lang--en/index.htm>.

${ }^{19}$ Kevin Kolben, 'Transnational Labor Regulation and the Limits of Governance' (2011) 12 Theoretical Inquiries in Law 403, 407.

${ }^{20}$ UN Working Group on Business and Human Rights, The UN Guiding Principles on Business and Human Rights: An Introduction (undated) <https://www.ohchr.org/Documents/ Issues/Business/Intro_Guiding_PrinciplesBusinessHR.pdf $>$ cited in Chilton and Sarfaty, above n 1, 8; Susan Marks, 'Empire's Law' (2003) 10(1) Indiana Journal of Global Legal Studies $449,461$.

${ }^{21}$ Steven R Ratner, 'Corporations and Human Rights: A Theory of Legal Responsibility' (2001) 111 Yale Law Journal 443, 460, 463 cited in Chilton and Sarfaty, above n 1, 8.
} 
and regulatory gaps ${ }^{22}$ and corruption, and human rights violations. ${ }^{23}$ These problems are not necessarily resolved by the efforts of international or intergovernmental institutions because their regulatory capacities are limited.

Affected workers are left without adequate legal or regulatory protection. According to the Business and Human Rights Resource Centre in 2017, ${ }^{24}$ up to 94 per cent of the global workforce of 50 major corporations was hidden because responsibility had been outsourced multiple times. Workers were thereby placed in a vulnerable situation, facing 'weak legal frameworks that fail to protect and uphold labour standards; business operations driven by the search for ever lower labour costs; and the increasingly complex nature of supply chains'. ${ }^{25}$ Suppliers, especially those operating informally, may respond to price or competition pressures by adopting employment arrangements which may not comply with labour regulations, and which may include forced and child labour. ${ }^{26}$

\section{EXAmples Of Supply Chain Human Rights PROBLEMS}

Global supply chains have brought with them some benefits, such as employment and economic growth, to developing economies. However, such chains are also frequently linked to 'exploitative employment relations, environmental irresponsibility and recurrent ethical dilemmas' ${ }^{27}$ According to the International Trade Union Confederation, in 201660 per cent of global trade was driven by big business which used a model based on exploitation and abuse

\footnotetext{
${ }^{22}$ Sarfaty, above n 13, 433.

${ }^{23}$ OECD, Risk Awareness Tool for Multinational Enterprises in Weak Governance Zones (2006) cited in Chilton and Sarfaty, above n 1, 8.

${ }^{24}$ The Business and Human Rights Resource Centre is a charitable organisation that assists communities and NGOs in their work of seeking to get companies to address human rights concerns by providing guidance and research analysis as well as advocacy. See further at $<$ https://www.business-humanrights.org/en/about-us $>$.

${ }^{25}$ Business and Human Rights Resource Centre ('BHRRC'), Modern Slavery in Company Operation and Supply Chains: Mandatory Transparency, Mandatory Due Diligence and Public Procurement Due Diligence (September 2017) <http://www.120argentina.org/pdf/modern slavery_in_company_operation_and_supply_chain_final.pdf $>2$.

${ }^{26}$ International Labour Office, Decent Work in Global Supply Chains, Report IV, International Labour Conference, 105 $5^{\text {th }}$ Session 2016, $3<$ http://www.ilo.org/ilc/ILCSessions/105/ reports/reports-to-the-conference/WCMS_468097/lang--en/index.htm>.

${ }^{27}$ Clarke and Boersma, above n 16, 111.
} 
of human rights in supply chains. ${ }^{28}$ Commentators have detailed many examples of human rights abuses, labour exploitation and other wrongs committed in the context of supply chains. Human Rights Watch, ${ }^{29}$ for example, documents: poor working conditions, including minimum wage violations; forced overtime; child labour; sexual harassment; exposure to toxic substances and other extreme occupational hazards; and retaliation against workers who attempt to organise. ${ }^{30}$ In the five years up to 2017,89 million people experienced some form of modern slavery globally, 82.7 million of whom were victims of forced labour, including trafficking. Modern slavery accounts for US $\$ 150$ billion of illicit profits in corporate supply chains across the world. $^{31}$

Duhigg and Barboza provide evidence of bleak working conditions throughout much of the electronics supply chain in Asia, ${ }^{32}$ and Clarke and Boersma identify Apple Inc (Apple) as providing a classic example of the problems that emerge in global value chains. Apple's efforts to eradicate problems and enforce higher standards in all of its suppliers have too often failed. When it was using supplies from China, where labour laws are weak and there are no enforcement procedures, Apple tried to fill the governance gap through private initiatives, including the creation in 2006 of a supplier code of conduct designed to achieve supplier responsibility. In its 2010 annual Supplier Responsibility Report the company stated that it "continues to improve and expand our supplier responsibility program to ensure that working conditions in our supply base are safe, workers are treated with respect and dignity, and manufacturing processes are environmentally responsible'. ${ }^{33}$ Yet despite Apple's efforts to ensure adherence to its Code, and the help it has enlisted from an independent auditor, since 2006 the company has continued to be criticised 'for sourcing

${ }^{28}$ International Trade Union Confederation, Scandal: Inside the Global Supply Chains of 50 Top Companies (2016) $4<\mathrm{https}$ ://www.ituc-csi.org/IMG/pdf/pdffrontlines_scandal_en-2.pdf $>$.

${ }^{29}$ Human Rights Watch is an NGO providing research and advocacy on human rights issues. See further $<$ https://www.hrw.org/about $>$.

${ }^{30}$ Human Rights Watch, Human Rights in Supply Chains: A Call for a Binding Global Standard on Due Diligence (30 May 2016) < https://www.hrw.org/report/2016/05/30/human-rightssupply-chains/call-binding-global-standard-due-diligence>.

${ }^{31} 8.7$ Alliance, 2017 Global Estimates: Modern Slavery and Child Labour (2017) <https://www. alliance 87. org $/ 2017 \mathrm{ge} / \#$ !section $=0>$.

${ }^{32}$ Charles Duhigg and David Barboza, 'In China, Human Costs Are Built into an iPad', New York Times (online) 25 Jan $2012<$ https://www.nytimes.com/2012/01/26/business/ieconomyapples-ipad-and-the-human-costs-for-workers-in-china.html>; David Barboza and Charles Duhigg., 'China Plant Again Faces Labor Issues on iPhones', New York Times (online), 10 September $2012<$ https://www.nytimes.com/2012/09/11/technology/foxconn-said-to-useforced-student-labor-to-make-iphones.html>.

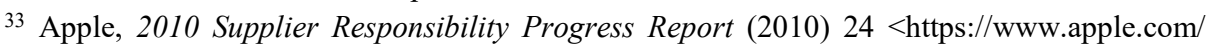
supplier-responsibility/pdf/Apple_SR_2010_Progress_Report.pdf $>$. 
components from producers that have a poor reputation with regard to employment conditions and practices' ${ }^{34}$ Apple may have been encouraged in its lapses by the fact that its customers continued to purchase its products regardless of its supply chain faults, generating record profits for the company. ${ }^{35}$ The efforts of stakeholders, media investigations, and independent audits had exposed the exploitation in Apple's supply chain ${ }^{36}$ but the awareness was not sufficient to energise consumers to challenge Apple. Rather, they appear to have been satisfied by Apple and one of its suppliers, Foxconn's, 'immense marketing efforts focused on the products themselves' and so exploitative practices continued. ${ }^{37}$

\section{INTERNATIONAL AND NATIONAL REgULATORY RESPONSES - TOWARDS A REQUIREMENT FOR Disclosure AND Due Diligence}

Recognising these problems, a number of international organisations have sought to guide corporate behaviour through the introduction of standards and principles. National legislatures have acted to supplement those international efforts. This section provides an overview of these measures.

\section{A United Nations}

In June 2011, the United Nations Human Rights Council (UNHRC) unanimously endorsed $31 \mathrm{UN}$ Guiding Principles on Business and Human Rights (UNGPs) ${ }^{38}$ based on the UN 'Protect, Respect and Remedy' Framework, approved in $2008^{39}$ and supporting the human rights enshrined within the Universal Declaration of Human Rights ${ }^{40}$ and the principles concerning

\footnotetext{
${ }^{34}$ Clarke and Boersma, above n 16, 117.

${ }^{35}$ Ibid 125.

${ }^{36}$ Ibid.

${ }^{37}$ Ibid 130.

${ }^{38}$ United Nations, Office of the High Commissioner for Human Rights, UN Guiding Principles on Business and Human Rights (2011) <http://www.ohchr.org/Documents/Publications /GuidingPrinciplesBusinessHR_EN.pdf $>$.

39 The 'Protect, Respect and Remedy' Framework developed by the Special Representative of the Secretary-General on Human Rights and Business was endorsed by UN member states in the UN Human Rights Council Resolution on the Mandate of the Special Representative of the Secretary-General on the issue of human rights and transnational corporations and other business enterprises (UN Human Rights Council, 2008).

${ }^{40}$ Universal Declaration of Human Rights, GA Res $217 \mathrm{~A}$ (III), UN GAOR, $3^{\text {rd }}$ sess, $183^{\text {rd }}$ plen $\mathrm{mtg}$, UN Doc A/810 (10 December 1948).
} 
fundamental rights in the eight International Labour Organization (ILO) core conventions ${ }^{41}$ as set out in the Declaration on Fundamental Principles and Rights at Work. ${ }^{42}$

UNGP 13 states that businesses should 'avoid causing or contributing to adverse human rights impacts through their own activities and address such impacts when they occur' and 'seek to prevent or mitigate adverse human rights impacts that are directly linked to their operations, products or services by their business relationships, even if they have not contributed to those impacts'. UNGP 15 states that business enterprises should have in place '[a] policy commitment to meet their responsibility to respect human rights'; '[a] human rights due diligence process to identify, prevent, mitigate and account for how they address their impacts on human rights'; and '[p]rocesses to enable the remediation of any adverse human rights impacts they cause or to which they contribute'.

These are supplemented by the ILO's Protocol of 2014 to the Forced Labour Convention of 1930 (No 29) ${ }^{43}$ with a Supplementary Recommendation Forced Labour (Supplementary Measures) Recommendation, 2014 (No 203) ${ }^{44}$ (aiming for 50 ratifications by the end of 2018); ${ }^{45}$ and the Tripartite Declaration of Principles Concerning Multinational Enterprises and Social Policy (the MNE Declaration) ${ }^{46}$

The UN Global Compact, ${ }^{47}$ a voluntary initiative of the UN, encourages businesses to adopt sustainable and socially responsible policies, and lays down ten principles in the areas of human rights, labour, the environment and anticorruption. In particular, businesses should: support and respect the protection of internationally proclaimed human rights (Principle 1); ensure that they are

41 Collected in International Labour Office, The International Labour Organization's Fundamental Conventions $(2002 / 3)<\mathrm{https} / /$ www.ilo.org/wcmsp5/groups/public/@ed_norm/ @ declaration/documents/publication/wcms_095895.pdf $>$.

${ }^{42}$ Declaration on Fundamental Principles and Rights at Work, International Labour Conference, Geneva, 86 ${ }^{\text {th }}$ sess (18 June 1998) (Annex revised 15 June 2010).

${ }^{43}$ Protocol of 2014 to the Forced Labour Convention, 1930 (No 29), opened for signature 11 June 2014, Geneva 103 ${ }^{\text {rd }}$ ILC Session, 11 June 2014 (entered into force 9 November 2016).

${ }^{44}$ International Labour Organization, Recommendation on Supplementary Measures for the Effective Suppression of Forced Labour, 2014 (No 203), adopted 103 ${ }^{\text {rd }}$ ILC sess, Geneva (11 Jun 2014).

${ }^{45}$ By October 2018 there were 27 ratifications.

${ }^{46}$ Tripartite Declaration of Principles Concerning Multinational Enterprises and Social Policy, International Labour Organization, 204 ${ }^{\text {th }}$ sess, Geneva (November 1977) (last amended March 2017).

${ }^{47}$ United Nations Global Compact $<$ https://www.unglobalcompact.org/about $>$. 
not complicit in human rights abuses (Principle 2); uphold the freedom of association and the effective recognition of the right to collective bargaining (Principle 3); eliminate all forms of forced and compulsory labour (Principle 4); effectively abolish child labour (Principle 5), and; eliminate discrimination in respect of employment and occupation (Principle 6).

\section{B OECD}

The OECD has developed in its Guidelines for Multinational Enterprises, ${ }^{48} \mathrm{a}$ set of non-binding recommendations addressed by governments to multinational enterprises, aimed at promoting responsible business conduct in a global context. It is designed to be consistent with applicable laws and internationally recognised standards. These Guidelines were revised in 2011 to take into account the UNGPs, the revisions introducing standards on human rights, due diligence and supply chain responsibility. They contain a dispute resolution process in which interested parties (including non-governmental organisations (NGOs) and trade unions) may make complaints against companies to a National Contact Point (NCP) - a body set up by governments to further the effectiveness of the Guidelines ${ }^{49}$ - who will resolve the dispute. Thus, whilst they are non-binding, the Guidelines have a hybrid status, requiring NCPs to further their effect. ${ }^{50}$ Since 2000 , NCPs have received more than 400 cases relating to company operations in over 100 countries and territories. The majority of cases deal with: employment and worker issues (54 per cent), human rights ( 28 per cent) and environment ( 20 per cent). Between 2011 and 2016, approximately half of all cases (47 per cent) which were accepted for further examination by NCPs resulted in some form of agreement between the parties; and approximately 37 per cent resulted in an internal policy change by the company in question. ${ }^{51}$

Additional guidance documents have been published by the OECD, such as the OECD Due Diligence Guidance for Responsible Supply Chains of Minerals

48 OECD, Declaration on International Investment and Multinational Enterprises, Annex: Guidelines for Multinational Enterprises, 1976, last revised in $2011<\mathrm{https}$ ://www.oecd.org /daf/inv/mne/48004323.pdf>.

49 See OECD, National Contact Points for the OECD Guidelines for Multinational Enterprises (2018) <http://www.oecd.org/daf/inv/mne/ncps.htm>.

50 Sander van't Foort, 'The History of National Contact Points and the OECD Guidelines for Multinational Enterprises' [2017] Journal of the Max Planck Institute for European Legal History 195.

51 OECD, Cases Handled by the National Contact Points for the OECD Guidelines for Multinational Enterprises (undated) <http://mneguidelines.oecd.org/Flyer-OECD-NationalContact-Points.pdf $>$. 
from Conflict-Affected and High-Risk Areas in 2011, ${ }^{52}$ the third edition of which was published in 2016, and the OECD Due Diligence Guidance for Responsible Supply Chains in the Garment and Footwear Sectors in 2017. ${ }^{53}$ Similarly, the OECD, together with the UN Food and Agriculture Organization, published Guidance for Responsible Agricultural Supply Chains in $2016 .{ }^{54}$ The OECD has recently published general due diligence guidance for responsible business conduct, addressed to multinational enterprises and groups, to complement the existing Guidelines and sector-specific due diligence guidance. ${ }^{55}$

\section{EU}

At the European level the Non-Financial Reporting Directive, ${ }^{56}$ making reference to the OECD Guidelines and the UNGPs, introduced a requirement for certain large undertakings (public interest entities) to include in their management reports a non-financial statement providing information on

environmental matters, social and employee-related matters, respect for human rights, anti-corruption and bribery matters. Such statement should include a description of the policies, outcomes and risks related to those matters and should be included in the management report of the undertaking concerned. The non-financial statement should also include information on the due diligence processes implemented by the undertaking, also regarding, where relevant and proportionate, its supply and subcontracting chains, in order to identify, prevent and mitigate existing and potential adverse impacts. ${ }^{57}$

52 OECD, Due Diligence Guidance for Responsible Supply Chains of Minerals from ConflictAffected and High-Risk Areas <http://www.oecd.org/corporate/mne/mining.htm>.

${ }^{53}$ OECD, Due Diligence Guidance for Responsible Supply Chains in the Garment and Footwear Sector (2017) <https://mneguidelines.oecd.org/oecd-due-diligence-guidance-garmentfootwear.pdf $>$.

${ }^{54}$ OECD-FAO, Guidance for Responsible Agricultural Supply Chains (14 October 2016) $<$ https://www.oecd-ilibrary.org/agriculture-and-food/oecd-fao-guidance-for-responsibleagricultural-supply-chains_9789264251052-en>.

55 See OECD, Due Diligence Guidance for Responsible Business Conduct (31 May 2018) $<\mathrm{http}$ ://www.oecd.org/investment/due-diligence-guidance-for-responsible-business-conduct. $\mathrm{htm}>$.

${ }^{56}$ Directive 2014/95/EU of the European Parliament and of the Council of 22 October 2014 amending Directive 2013/34/EU as regards Disclosure of Non-Financial and Diversity Information by Certain Large Undertakings and Groups [2014] OJ L 330/1, 1-9.

${ }^{57}$ Ibid, Preamble, para 6. 
The statement might also include information on the prevention of human rights abuses and on measures taken to prevent bribery or corruption. ${ }^{58}$

As well as the EU's Non-Financial Reporting Directive, the EU Regulation $2017 / 821^{59}$ was introduced, applicable since January 2017, which establishes obligations related to management systems, risk management, and independent third-party audits for importers of conflict minerals. ${ }^{60}$ Such importers must prepare annual reports on the steps taken to implement those obligations as well as their due diligence policies and practices for responsible sourcing, and they must make available to their governments third party audit reports or evidence of conformity with a supply chain due diligence scheme. The European Parliament has introduced a 'flagship initiative' calling for similar due diligence requirements in the garment sector. ${ }^{61}$ In addition, an EU 'green card initiative' ${ }^{62}$ proposes that EU-based companies operate under a duty of care towards individuals and local communities whose human rights or local environment are affected by corporate activities, and Motion 2015/258963 requests the European Council to consider new EU legislation to create a legal obligation of due diligence to require EU companies outsourcing to third countries to pursue measures to secure traceability and transparency. The European Parliament also passed a resolution in September 2017 responding to motion 2015/2589 - 2016/2301 (INI) - on the impact of international trade and the EU's trade policies on global value chains. The resolution, among other things, called on the Commission to work on the development of due diligence requirements. ${ }^{64}$

\footnotetext{
${ }^{58}$ See also art 1(1) and 1(3) of Directive 2014/95/EU.

${ }^{59}$ Regulation (EU) 2017/821 of the European Parliament and of the Council of 17 May 2017 laying down supply chain due diligence obligations for Union importers of tin, tantalum and tungsten, their ores, and gold originating from conflict-affected and high-risk areas.

${ }^{60}$ Conflict minerals are defined by the OECD as minerals or metals from conflict-affected and high-risk areas; see Due Diligence Guidance, above n 52.

${ }^{61}$ Resolution of 27 April 2017 on the EU Flagship Initiative on the Garment Sector, 2016/2140(INI), leading to the publication by the European Commission of a Commission Staff Working Document: Sustainable Garment Value Chains through EU Development Action (2017) $147<$ http://parltrack.euwiki.org/dossier/2016/2140(INI)>.

${ }^{62}$ The 'green card' is a mechanism for enhanced political dialogue, enabling national parliaments jointly to propose to the European Commission new legislative or non-legislative initiatives, or changes to existing legislation.

${ }^{63}$ European Parliament Resolution on the Second Anniversary of the Rana Plaza Building Collapse and Progress of the Bangladesh Sustainability Compact (2015/2589(RSP)) $<$ http://www.europarl.europa.eu/sides/getDoc.do?type=MOTION\&reference=P8-RC-2015$0363 \&$ language $=\mathrm{EN}>$.

64 See Business and Human Rights Resource Centre (12-13 September 2017) $<$ https://www.business-humanrights.org/en/european-parliament-passes-resolution-on-impact-
} 


\section{National Measures}

National measures take the form either of disclosure requirements or of due diligence requirements. For disclosure-oriented transparency the most widely publicised developments include the California Transparency in Supply Chains Act 2010 and the UK's Modern Slavery Act 2015.

The California Transparency in Supply Chains Act 2010 (now included in the California Civil Code) requires website disclosure of any actions taken to eradicate slavery and human trafficking from a corporation's direct supply chain for tangible goods offered for sale. The company must disclose on its website to 'what extent, if any' it:

(1) Engages in verification of product supply chains to evaluate and address risks of human trafficking and slavery. The disclosure shall specify if the verification was not conducted by a third party.

(2) Conducts audits of suppliers to evaluate supplier compliance with company standards for trafficking and slavery in supply chains. The disclosure shall specify if the verification was not an independent, unannounced audit.

(3) Requires direct suppliers to certify that materials incorporated into the product comply with the laws regarding slavery and human trafficking of the country or countries in which they are doing business.

(4) Maintains internal accountability standards and procedures for employees or contractors failing to meet company standards regarding slavery and trafficking.

(5) Provides company employees and management, who have direct responsibility for supply chain management, training on human trafficking and slavery, particularly with respect to mitigating risks within the supply chains of products. ${ }^{65}$

A company may comply with the law by posting only one statement ever, since the Act does not specify how frequently a statement must be made. ${ }^{66}$ The California Attorney-General has exclusive authority to enforce the legislation, leading a civil action for injunctive relief. Companies do not face a monetary penalty for failure to disclose, but the Attorney-General may order them to take

\footnotetext{
of-intl-trade-eu-policies-on-global-value-chains-encouraging-more-transparency-on-eucustoms-data>.

${ }^{65} \mathrm{Cal}$ Civ Code $\S 1714.43(\mathrm{c})$.

${ }^{66}$ BHRRC, above n 25, 8 .
} 
specific action. Citizens have no private right of action under the Act. A federal US Business Transparency in Trafficking and Slavery Bill ${ }^{67}$ targets all businesses with revenues above US $\$ 100$ million and, if enacted, will require them to describe in their annual reports how they assess and address slavery in their supply chains. ${ }^{68}$

In the UK, section 54 of the Modern Slavery Act 2015 (Modern Slavery Act) requires any commercial organisation which supplies goods or services, carries on a business or part of a business in the UK, and whose annual turnover is not less than $£ 36$ million to produce a slavery and human trafficking statement for each financial year. The report must provide details of what the organisation is doing to 'ensure that slavery and human trafficking is not taking place in any of its supply chains, and in any part of its own business'. Section 54(5) contains a non-exhaustive list of the issues that the statement 'may' cover: 'the organisation's structure, its business and its supply chains'; 'its policies in relation to slavery and human trafficking'; 'its due diligence processes in relation to slavery and human trafficking in its business and supply chains'; 'the parts of its business and supply chains where there is a risk of slavery and human trafficking taking place, and the steps it has taken to assess and manage that risk'; 'its effectiveness in ensuring that slavery and human trafficking is not taking place in its business or supply chains, measured against such performance indicators as it considers appropriate'; and 'the training about slavery and human trafficking available to its staff'. If a company fails to produce a slavery and human trafficking statement for a particular financial year the UK Secretary of State may seek an injunction from the High Court requiring the organisation to comply. ${ }^{69}$ Some have suggested that this would be 'an unlikely course of action' ${ }^{70}$ though failure to comply with any such injunction would put the company in contempt of a court order, punishable by an unlimited fine.

Neither of these disclosure laws is especially strong. Neither law requires companies to report on the extent of modern slavery in their operations or supply chains, nor do they require companies to take steps to prevent slavery in

\footnotetext{
${ }^{67}$ Business Transparency in Trafficking and Slavery Act, HR 2759, $112^{\text {th }}$ Congress (2011).

${ }^{68}$ Ibid $\S 2$.

${ }^{69}$ Modern Slavery Act 2015 (UK) s 54(11).

70 Simon Shooter, The Modern Slavery Act: An Update (12 September 2017) Bird \& Bird $<$ https://www.twobirds.com/en/news/articles/2017/uk/the-modern-slavery-act-update>.
} 
their operations or supply chains. ${ }^{71}$ Companies have no need to report or to implement robust due diligence processes. ${ }^{72}$

Unsurprisingly, the Modern Slavery Act has not led to full and effective disclosure by corporations. In 2016, the Business and Human Rights Resource Centre found that only 15 of 27 statements analysed (56 per cent) complied with the minimum requirements. Its analysis showed 'patchy compliance with the substantive provisions of the Act'. ${ }^{73}$ Only a small number of the 27 FTSE 100 companies analysed provided information on risks they identified in their operations and supply chains and explained how they addressed them. Most companies provided little information on the structure and complexity of their supply chains. Only two companies reported developing performance indicators. ${ }^{74}$ A subsequent briefing released in June 2017 by CORE Coalition revealed that only around 14 per cent of over 2100 statements under the Act comply with the minimum requirements and most of those provide little information on the six areas the Act suggests that companies report on. ${ }^{75}$ According to a 2016 review by Ergon Associates of 230 Modern Slavery Act company statements, most fail to comply with minimum requirements. Forty per cent had not been signed by a director, and about 30 per cent were not accessible via a link easily found on the company's website. ${ }^{76}$ Ergon's review also noted poor reporting on key performance indicators, and that 35 per cent of statements 'say nothing on the question of their risk assessment processes' ${ }^{77}$ In light of the recognised weaknesses, a private members bill was introduced in

\footnotetext{
${ }^{71}$ BHRRC, above $\mathrm{n} 25,10$.

${ }^{72}$ Ibid 11. Note also that the Australian government has announced its intention to introduce a Modern Slavery in Supply Chains Reporting Requirement. The Australian government clarifies in its consultation that its proposal will not require due diligence but is to be a reporting requirement (Modern Slavery in Supply Chains Reporting Requirement - Public Consultation Paper, 16 August $2017<\mathrm{https}$ ://www.ag.gov.au $>$ ). The proposal has been criticised for failing to mandate a due diligence requirement or to impose any penalties for non-compliance, as well as being targeted at only the largest of companies, with annual revenues of AUD100 million or more (Komala Ramachandra, 'Australia's 'Modern Slavery' Proposal Falls Short', Human Rights Watch (online), 5 September $2017<$ https://www.hrw.org $>$ ).

${ }^{73}$ BHRRC, above $\mathrm{n} 25,13$.

${ }^{74}$ Ibid 13.

${ }^{75}$ CORE, Modern Slavery Reporting: Weak and Notable Practice (June 2017) <http://corporateresponsibility.org/wp-content/uploads/2017/06/Core_ExamplesFINAL.pdf $\$$.

${ }^{76}$ Ibid.

${ }^{77}$ Ergon Associates, Reporting on Modern Slavery: The Current State of Disclosure (May 2016) $<$ http://ergonassociates.net/wp-content/uploads/2017/06/Reporting-on-Modern-Slavery2May-2016.pdf?x74739>; see also Ergon Associates, Modern Slavery Statements: One Year On (April 2017) <http://ergonassociates.net/wp-content/uploads/2016/03/MSA_One_year_on_ April_2017.pdf?x74739>.
} 
the House of Lords in 2017 seeking to amend section 54(5) of the $\mathrm{Act}^{78}$ to make the suggested transparency statement mandatory, and to require an organisation that declares it has taken no steps to eradicate slavery and human trafficking from its supply chain and business to explain its reasons for not doing so.

Going further than the steps taken in California and the UK, some states have adopted due diligence laws. These require a company to go beyond simply making statements about its policies for dealing with risks of human rights abuses or environmental damage and to demonstrate that it is taking measures to prevent or mitigate any negative impacts. ${ }^{79}$ Due diligence is defined by the $\mathrm{UN}$ and the OECD as a risk-based process 'through which enterprises can identify, prevent, mitigate and account for how they address their actual and potential adverse impacts'. The OECD Guidance on Due Diligence for Responsible Business Conduct recommends a six-step framework which includes 1) embedding responsible business conduct into policies and management systems; 2) identifying and assessing adverse impacts in operations, supply chains and business relationships; 3) ceasing, preventing or mitigating adverse impacts; 4; tracking implementation and results; 5) communicating how impacts are addressed; and 6) providing for or cooperating in mediation when appropriate. ${ }^{80}$

France recently introduced Law 2017-399 81 on the corporate duty of care owed by parent and subcontracting companies. Under this law, companies have reporting obligations and they must implement a due diligence plan (plan de vigilance) and exercise 'reasonable vigilance' to make sure the plan is implemented. ${ }^{82}$ The plan will describe, annually, the company's oversight mechanisms for identifying and mitigating any violations of human rights and fundamental freedoms, severe bodily or environmental damage, or health risks resulting from the company's activities or the activities of companies it controls or any of its subcontractors or suppliers. ${ }^{83}$ The French law does not require that slavery or trafficking be eradicated, but that companies engage in oversight. ${ }^{84}$

\footnotetext{
${ }^{78}$ Modern Slavery (Transparency in Supply Chains) Bill 2017.

${ }^{79}$ BHRRC, above n 25, 4.

${ }^{80}$ OECD, above n 55, 21-35.

${ }^{81}$ Loi $n^{\circ}$ 2017-399 du 27 mars 2017 relative au devoir de vigilance des sociétés mères et des entreprises donneuses d'ordre (1) NOR: ECFX1509096L <https://www.legifrance. gouv.fr/eli/loi/2017/3/27/2017-399/jo/texte>.

82 Ibid.

${ }^{83}$ BHRRC, above n 25, 17.

84 Jena Martin, 'Hiding in the Light: The Misuse of Disclosure to Advance the Business and Human Rights Agenda' (2017) 56 Columbia Journal of Transnational Law 530.
} 
The Netherlands is currently in the process of legislating for a duty of care to prevent child labour. The relevant Act would be the Wet zorgplicht kinderarbeid. Under the proposed legislation, companies selling or delivering products or services to Dutch end users would be required to investigate and identify whether there is a reasonable suspicion that child labour is contributing to their delivering or selling of goods or services in their chain. If such a suspicion arose, a company would have to develop a plan of action to address it and issue a due diligence statement. A supervising authority would be appointed to monitor compliance with the Act. The statement would be recorded in a public register, which would also be held by the supervising authority, thought likely to be the Dutch Authority on Consumers and Markets. ${ }^{85}$ This law, if passed, would provide that any stakeholder who has clear evidence that a company has used child labour to produce goods or services would be able to submit a complaint to that company. If the company did not resolve the complaint satisfactorily with the stakeholder within six months, the stakeholder would then be able to submit the complaint to Dutch authorities, who might issue a legally-binding instruction ordering the company to conduct the required due diligence and make the appropriate declaration. A failure by the company to comply with the instruction would result in a fine of up to EUR 820000 or, alternatively, 10 per cent of the company's annual turnover, and two or more failures within five years might lead to criminal penalties and more substantial fines. The companies that would be covered by the legislation include not only companies that are registered with the Dutch trade register but also foreign companies if they deliver goods or services to end-users in the Netherlands more than once a year. ${ }^{86}$ At the time of writing, the law awaits approval by the Dutch Senate although its future status is unclear.

Switzerland is also working towards a potential article 101(a) in the Federal Constitution concerning the responsibility of business. Its goal would be to oblige Swiss companies to incorporate respect for human rights and the environment in all their activities. If enacted, this new constitutional provision would have extraterritorial effect by applying also to Swiss-based companies' activities abroad. Under the proposal, companies would be required to carry out appropriate due diligence. Companies would also be liable for damage caused by companies under their control where these latter companies have, in the course of business, committed violations of internationally recognised human

\footnotetext{
${ }^{85}$ Barbara Bier, Daan Doorenbos and Christien Saris, 'Bill Adopted by Dutch Parliament Introducing a Duty of Care to Prevent Child Labour' Stibbe (22 May 2017) $<$ https://www.stibbe.com/en/news/2017/may/bill-adopted-by-dutch-parliament-introducing-aduty-of-care-to-prevent-child-labour>.

${ }^{86}$ Ibid.
} 
rights or international environmental standards. They would not be liable, however, if they could prove that they took all due care to avoid the loss or damage, or that the damage would have occurred even if all due care had been taken. ${ }^{87}$

This 'Responsible Business Initiative' (RBI) is a popular initiative brought by a coalition led by NGOs, including Greenpeace and Amnesty International, and is supported by 85 organisations working in international aid, women's and human rights and environmental protection, as well as churches, unions and shareholders' associations. In Switzerland, most popular initiatives do not achieve the required formal approval to become law. However, even if unsuccessful, a popular initiative may still shape the political landscape by generating public debate, highlighting specific issues and putting pressure on politicians ${ }^{88}$ On 14 June 2018, the Swiss National Council approved a counterproposal to the citizen RBI by a majority of 121 votes in favour (73 against). The counter-proposal establishes human rights obligations for Swiss companies with respect to their overseas impacts, as well as civil liability for parent companies for the harm caused by entities under their control. The National Council's counter-proposal represents a compromise between the views of the RBI's proponents, the Parliament and the business community. As a compromise, the counter-proposal is not as far-reaching as the RBI in that it applies to large companies and the civil liability provisions are more restrictive. If this counter-proposal is accepted by the Council of State and adopted, the RBI will be withdrawn. ${ }^{89}$

It is perhaps too early to judge the above due diligence provisions because the French law is very recent, and the Netherlands and Swiss provisions are still going through the development processes and may not materialise as full laws. In any event, whilst due diligence is an advance, such an approach does not guarantee the prevention of negative impacts. Thus, for example, the French Law does not require eradication of slavery or trafficking, but rather that companies make efforts to eradicate or reduce those risks and be able to demonstrate such efforts.

\footnotetext{
87 Swiss Coalition for Corporate Justice, The Initiative Text with Explanations (undated) $<$ http://konzern-initiative.ch/wp-content/uploads/2017/11/The-initiative-text-with-explanat ions.pdf>.

88 Julianne Hughes-Jennett et al, 'Switzerland: The Next Frontier for Mandatory Human Rights Due Diligence?' Hogan Lovell (1 December 2017) <https://www.hlregulation.com/ 2017/12/01/switzerland-the-next-frontier-for-mandatory-human-rights-due-diligence/>.

${ }^{89}$ Swiss Coalition for Corporate Justice, 'Another Step towards the Adoption of a Mandatory HRDD Bill in Switzerland' (16 June 2018) <http://corporatejustice.org/news/7046-anotherstep-towards-the-adoption-of-a-mandatory-hrdd-bill-in-switzerland>.
} 
Overall, the most established legislation is perhaps the Modern Slavery Act but unfortunately the impact results do not give cause for celebration. The Modern Slavery Index of $2017,{ }^{90}$ which assessed 198 countries on the strength of their laws, the effectiveness of their enforcement and the severity of violations, reported an increased risk of slavery in 20 EU countries and across the world, as the current migration crisis increases the possibility of human trafficking and forced labour. ${ }^{91}$ The Global Estimates of Modern Slavery Report, published by Alliance $8.7,{ }^{92}$ found that in 2016 across the globe there were an estimated 40.3 million men, women and children who were victims of slavery, 24.9 million of these being in forced labour, including 16 million in forced labour in the private sector, 4.1 million in state labour and 4.8 million in forced sexual exploitation. ${ }^{93}$ According to the ITUC's Global Rights Index 2017, ${ }^{94}$ the number of countries experiencing physical violence and threats against workers rose by ten per cent in the previous year, with corporate interests being prioritised and workers being denied labour law protections across the global economy. ${ }^{95}$

\section{THE PROBLEMS AND Limitations OF TRANSPARENCY}

Transparency through disclosure brings with it grand promises of 'regulation by revelation'96: of greater trust, more participation, a more efficient

\footnotetext{
90 Verisk Maple, Modern Slavery Index 2017 (10 August 2017) <https://www.maple croft.com/portfolio/new-analysis/2017/08/10/20-eu-countries-see-rise-modern-slavery-risksstudy/>.

${ }^{91}$ International Labour Organization (ILO), Global Estimates of Modern Slavery: Forced Labour and Forced Marriage (2017) <http://www.ilo.org/global/publications/books/WCMS_575479/ lang--en/index.htm $\geq$. See also Verisk Maplecroft, Modern Slavery Index 2017 (10 August 2017) <https://maplecroft.com/portfolio/new-analysis/2017/08/10/20-eu-countries-see-risemodern-slavery-risks-study/>.

928.7 Alliance, Global Estimates of Modern Slavery: Forced Labour and Forced Marriage (2017) < https://www.ilo.org/wcmsp5/groups/public/---dgreports/---dcomm/documents/public ation/wcms_575479.pdf $>$.

${ }^{93}$ ILO, above n 91, 10.

${ }^{94}$ See International Trade Union Confederation, Global Rights Index 2017 (2017) <https://www. ituc-csi.org/ituc-global-rights-index-2017>.

${ }^{95}$ Ibid.

${ }^{96}$ Aarti Gupta, 'Transparency under Scrutiny: Information Disclosure in Global Environmental Governance' (2008) 8(2) Global Environmental Politics 1, 2 quoting Ann Florini, 'The End of Secrecy' [1998] (111) Foreign Policy 50.
} 
administration ${ }^{97}$ and less corruption. ${ }^{98}$ A moral basis for the demand for disclosure is the need to ameliorate the impact of corporate activities on others. ${ }^{99}$ By reducing information asymmetries, disclosure may enable weaker parties to participate more effectively in this process of amelioration and hold the corporate actors to account more easily. ${ }^{100}$ However, whilst disclosure might be regarded as an important mechanism for aligning shareholder and management interests ${ }^{101}$ it could inadvertently downplay the effects of bad behaviour or provide a reputational advantage without actually changing behaviours substantively. ${ }^{102}$

Disclosure regulation is based on an 'assumption that information matters and information can empower'. ${ }^{103}$ However, such empowerment depends on the information being valuable, accessible, comprehensible and comparable. ${ }^{104}$ Yet difficulties stand in the way of effective and empowering disclosure regulation, including the proliferation of measures that may compete with or contradict each other, the commodification of information, power reinforcement, information overload and the lack of enforcement or remediation.

\section{A Proliferation of Measures}

The multiplicity of measures aimed at effecting transparency contributes to inconsistencies and lack of coherence. This has been the experience in environmental reporting where multiple frameworks, and tension between the

\footnotetext{
${ }^{97}$ Martial Pasquier, 'La transparence: De la lumière à l'aveuglement?' Huffington Post (online),

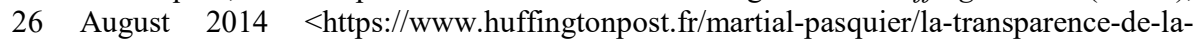
lumiere-a-l-aveuglement_b_5707117.html>.

${ }^{98}$ Vincent Mabillard and Raphael Zumofen, 'The Complex Relationship between Transparency and Accountability: A Synthesis and Contribution to Existing Frameworks' (2017) 32 Public Policy and Administration 110, 111-2, citing A Etzioni, 'Is Transparency the Best Disinfectant?' (2010) 18 Journal of Political Philosophy 389.

${ }^{99}$ Klaus Dingwerth and Margot Eichinger, 'Tamed Transparency: How Information Disclosure under the Global Reporting Initiative Fails to Empower' (2010) 10(3) Global Environmental Politics 74, 79.

${ }^{100}$ Arthur P J Mol, 'Transparency and Value Chain Sustainability' (2015) 107 Journal of Cleaner Production 154, 154.

101 Niamh M Brennan and Jill Solomon, 'Corporate Governance, Accountability and Mechanisms of Accountability: An Overview' (2008) 21 Accounting, Auditing and Accountability Journal 885; David Hess, 'Social Reporting and New Governance Regulation: The Prospects of Achieving Corporate Accountability through Transparency' (2007) 17 Business Ethics Quarterly 453.

102 Martin, above n 84, 37.

${ }^{103}$ Gupta, above n 96, 3.

${ }^{104}$ Dingwerth and Eichinger, above n 99, 75, citing Archon Fung, Mary Graham and David Weil, Full Disclosure: The Perils and Promise of Transparency (Cambridge University Press, 2007).
} 
corporate and stakeholder objectives have 'produced a number of governance systems that might be applied simultaneously and to different effect and for different constituencies'. ${ }^{105}$ As Backer observes, 'In the aggregate, these transparency systems are incoherent, making miscommunication likely and assessment across systems difficult'. ${ }^{106}$

\section{B Marketisation}

Emphasis on business case arguments for disclosure has turned the processes into a means for corporations to secure market leadership ${ }^{107}$ rather than to reduce the problems that their activities bring about. Disclosure has therefore become increasingly marketised or commodified ${ }^{108}$ with the result that disclosure systems often compete with, and are shaped by, investor and consumer tastes rather than by science and policy. ${ }^{109}$ Mol, for example, notes that new intermediaries/powerbrokers facilitate, translate, certify, interpret and articulate information in order to make it available and useful for different categories inside and outside value chains and networks. ${ }^{110}$

\section{Power}

In supply chains lead companies seize power over the actors further down the supply chain not just in their production processes but also in the disclosures made. ${ }^{111}$ Lead firms have the ability to 'drive coordination, enforce agreements, transmit environmental and human rights norms, and conduct due diligence along their supply chains'. ${ }^{112}$ For example, Backer observes that Walmart has managed to control the flow and coordination of supplier information, and the presence of clear, strict supplier standards allows Walmart to present practice failures along its supply chain as failures at the supplier and not the distributor level. ${ }^{113}$ Sometimes, however, the suppliers may have power over the buyer firms, such as when the buyer or lead firm faces high switching costs or lacks

\footnotetext{
${ }^{105}$ Larry Cata Backer, 'Transparency between Norm, Technique and Property in International Law and Governance: The Example of Corporate Disclosure Regimes and Environmental Impacts' (2013) 22(1) Minnesota Journal of International Law 1, 49.

${ }^{106}$ Ibid 51.

${ }^{107}$ Dingwerth and Eichinger, above $\mathrm{n} 99,80$.

${ }^{108}$ Backer, above n 105, 66.

${ }^{109}$ Ibid 70.

${ }^{110}$ Mol, above n 100, 155.

${ }^{111}$ Ibid 157.

${ }^{112}$ Sarfaty, above n 13, 432.

${ }^{113}$ Backer, above n 105, 47.
} 
the purchasing power to hold its suppliers captive. In such circumstances the lead firm has greater difficulty exercising due diligence, being forced to tolerate non-compliant and opportunistic behaviour by suppliers, especially those located at a distance from the lead firm. ${ }^{114}$

\section{The Recipients of Information}

Cooper and Owen observe that corporate disclosures offer organisational stakeholders little opportunity for facilitating action and therefore do not give rise to accountability. ${ }^{115}$ With respect to the human rights interests of consumers, for example, the disclosures made are not always sufficient to enable consumers to identify which companies are making comprehensive efforts to protect human rights and which are not. ${ }^{116}$ Nor are consumers able to determine from the information given to them the extent of human rights abuses in supply chain processes. Consumers also face information overload or 'data fog, ${ }^{117}$ being swamped by too many or too technically complex disclosures. ${ }^{118}$ They become further disempowered. ${ }^{119}$

\section{E Lack of Enforceability}

The UN initiatives have been very important in establishing a business and human rights agenda but they have been criticised by major NGOs and academics for their non-binding status as well as their lack of reference to issues such as extraterritorial adjudication, and the absence of a central mechanism to ensure their universal implementation. ${ }^{120}$ Positive claims made by the OECD about its dispute process are also contested by critics who regard the process as 'no longer fit for purpose'. For example, in the UK, Amnesty International UK exposes the OECD Guidelines as a system that lets companies off the hook when human rights abuses are alleged against them. ${ }^{121}$ Similarly, OECD Watch

\footnotetext{
${ }^{114}$ Sarfaty, above n 13, 433.

115 Stuart M Cooper and David L Owen, 'Corporate Social Reporting and Stakeholder Accountability: The Missing Link’ (2007) 32 Accounting, Organizations and Society 649.

${ }^{116}$ Chilton and Sarfaty, above n 1, 46.

117 David Shenk, Data Smog. Surviving the Information Glut (Harper Collins, 1997), cited by Mol, above n 100, 158.

${ }^{118}$ Chilton and Sarfaty, above n 1, 22.

${ }^{119}$ Mol, above n 100, 158.

120 European Parliament, Policy Department, Directorate-General for External Policies, Implementation of the UN Guiding Principles on Business and Human Rights (2017) 13.

121 Amnesty International, Obstacle Course: How the UK's National Contact Point Handles Human Rights Complaints under the OECD Guidelines for Multinational Enterprises (2016) $<$ https://www.amnesty.org.uk/files/uk_ncp_complaints_handling_full_report_lores_0.pdf $>$.
} 
states that 'far too many complaints are rejected outright, and of those accepted, the vast majority do not result in outcomes that end corporate misconduct, provide victims with remedies for harms incurred, or bring about changes to corporate behaviour'. ${ }^{122}$

In light of these weaknesses it is no wonder that commentators conclude, as does Mol, that 'transparency-in-practice has many shortcomings, practical limitations, dysfunctionalities or pathologies'. ${ }^{123}$ The limitations exposed by such commentators are manifested also by the fact that they appear to have been ineffective in reducing the number of those experiencing exploitation. We still witness human rights abuses, environmental damage, and labour exploitation. The ITUC Secretary General remarks on a hidden workforce, with states and corporations refusing to take responsibility, the result being that fundamental rights are undermined by corporate interests. ${ }^{124}$

\section{SOME SOLUTIONS}

What must be done to make the regulation of multinational companies and supply chains more effective? Commentators point out that effective approaches to human rights issues in global supply chains are characterised by companies engaging with a broad range of stakeholders.

Of relevance are the power relationships that occur in supply chains. The Institute for Global Law and Policy (IGLP) recognises that "law constitutes the power relations between actors that give rise to particular forms of governance and engender particular distributive effects'. The IGLP tells us that

[t]his focus on the role that legal frameworks play at different levels of a particular chain, and on the politico-economic power dynamics that operate behind competing legal norms, can help facilitate a critical assessment of the structural and distributional dimensions of GVCs - and the global economy more broadly - that are often taken for granted or normalised. Such an imaginative legal exercise can then help to elucidate alternative and

\footnotetext{
122 OECD Watch, 'OECD Watchdog Calls for Reform of Failing Complaint System' (15 June 2015) <https://www.oecdwatch.org/news-en/oecd-watchdog-calls-for-reform-of-failing-com plaint-system>, and see OECD Watch, C Daniel et al, Remedy Remains Rare (June 2015) $<$ https://www.oecdwatch.org/publications-en/Publication_4201>.

${ }^{123}$ Mol, above n 100, 155.

${ }^{124}$ See International Trade Union Confederation, above n 94.
} 
potentially more progressive sites of intervention by scholars, policymakers and civil society groups. ${ }^{125}$

From this perspective, it becomes important to examine what is really going on in these supply chains. It is easy to overlook the exploitative behaviours that permeate many of these structures which are described as global supply chains or global value chains.

Selwyn argues that a reformulation of 'global value chains' as 'global poverty chains' provides a concept that better comprehends the global dynamics of wealth concentration, and the (re)production of poverty and inequality. ${ }^{126}$ The term 'global value chain' shows how lead firm chain governance impacts upon supplier firm upgrading strategies and illuminates effectively how corporate decisions and practices in one part of the world impact upon developmental processes in another part of the world. However, it contains developmental bias since the supplier firm is presented as 'upgrading' its procedures to provide a route to poverty reduction and development. ${ }^{127}$ In these global value chain structures, Selwyn tells us, lead firm monopolistic, value-capturing and profitmaximising strategies are combined with exploitative supplier-firm strategies of capital accumulation to provide employment with deleterious effects upon workers, including poverty pay and unfree labour. ${ }^{128}$ As Andrew Crane explains, "value distribution along the supply chain, insofar as a particular stage is associated with very low-value capture, can provide significant pressure towards slavery'. ${ }^{129}$ Thus, rather than seeing global value chains as developmental organisations that raise people from poverty, the capitalist exploitation of labour within these structures 'immiserates' those working for them and keeps them in poverty. The Schumpeterian search by firms for new technologies, new markets, new sources of supply and new ways of making things may have the goal of improving supplier firm efficiency, competitiveness, adaptability and ability to link up to dynamic lead firms in

\footnotetext{
125 The IGLP Law and Global Production Working Group, above n 11, 61.

${ }^{126}$ Selwyn, 'Global Value Chains or Global Poverty Chains? A New Research Agenda', above n 2, 2. See also Selwyn, 'Social Upgrading and Labour in Global Production Networks: A Critique and an Alternative Conception', above $\mathrm{n} 2$.

${ }^{127}$ Selwyn, 'Global Value Chains or Global Poverty Chains? A New Research Agenda', above n 2,4 .

${ }^{128}$ Ibid 5.

${ }^{129}$ Andrew Crane, 'Modern Slavery as a Management Practice: Exploring the Conditions and Capabilities for Human Exploitation' (2013) 38 Academy of Management Review 49, 54, cited by G LeBaron, 'The Coming and Current Crisis of Indecent Work' in C Hay and T Hunt (eds), The Coming Crisis (Palgrave MacMillan, 2018) 43, 47.
} 
'value-adding' ways, ${ }^{130}$ but it is also driven by profit-maximisation leading to cost cutting and attempts to reap greater value and productivity from the workers by exploiting their labour. This might be seen as another example of the global south effectively subsidising the wealth of the global north, as was recently argued by Hickel in his book The Divide. ${ }^{131}$ In short, Selwyn tells us that these chains effectively reinforce poverty through exploitative arrangements:

First, lead firms use their oligopoly power to capture the Lion's share of the value created in each chain. Second, employment in these industries does not represent 'the first rung on the ladder out of extreme poverty', but, on the contrary, generates new forms of poverty. Third, lead firms play a significant part in generating these poverty-inducing conditions which in turn enables them to capture the majority share of value created in these chains. ${ }^{132}$

The formation and expansion of super-exploited labouring classes across developing countries in the global south facilitates northern firm accumulation strategies. The latter firms can threaten 'their' workers with outsourcing in order to repress wages, lengthen the working day, and intensify work. The production of very cheap goods by super-exploited workers across the global south enables northern workers to maintain relatively high levels of consumption whilst experiencing stagnant/falling wages. ${ }^{133}$ Thus, the impact is felt by workers in both the global south and the global north, since the poverty wages paid to those in the south lead to a driving down of wages in the north too as a result of the offshoring. ${ }^{134}$

\section{A Exploitation}

These global poverty chains are coordinated by powerful, multinational lead firms that source high quality goods and services at the lowest cost. Thus, through their own profit-seeking behaviour, they exploit the workers at the base of their value chains. ${ }^{135}$ Such firms operate by externalising the responsibilities for the production process and for how the workers are treated. At the same

\footnotetext{
${ }^{130}$ Selwyn, 'Global Value Chains or Global Poverty Chains? A New Research Agenda', above n 2,35 .

${ }^{131}$ Jason Hickel, The Divide: A Brief Guide to Global Inequality and its Solutions (Heinemann, 2017).

${ }^{132}$ Selwyn, 'Global Value Chains or Global Poverty Chains? A New Research Agenda', above n 2, 17 (citation omitted).

${ }^{133}$ Ibid 36.

${ }^{134}$ Ibid 33.

${ }^{135}$ Rawling, above n 4, 661.
} 
time, they use their powerful position to keep the production costs low and to maximise their profits. Clarke and Boersma's case study of Apple provides an example of this dynamic. The authors highlight how Apple externalises its responsibilities through its Supplier Code of Conduct and therein demands that

suppliers ... provide safe working conditions, treat workers with dignity and respect, act fairly and ethically, and use environmentally responsible practices wherever they make products or perform services for Apple .... Apple will assess its suppliers' compliance with this Code, and any violations of this Code may jeopardize the supplier's business relationship with Apple, up to and including termination. ${ }^{136}$

Alongside this Code of Conduct requirement, Apple demands from its suppliers high quality goods and services at the lowest prices possible. The supplier is therefore left with little choice but to cut its own production costs and to pass those on by paying lower wages to the workers and leaving them to work in unsafe production facilities. The externalising of responsibilities is pushed onto those who have no way to externalise them further, and those are the workers who have little labour law protection and who are forbidden to form independent trade unions or to strike, as is the case for the workers in Apple's Chinese suppliers. ${ }^{137}$

This exploitative form of organisation is an essential feature of these production chains. The recognition of this exploitation might encourage adoption of an alternative approach, analytically prioritising workers' attempts to ameliorate their conditions. ${ }^{138}$ Selwyn compares a social upgrading analysis with an analysis of the labour process and concludes:

While advocates of social upgrading and Decent Work represent a 'topdown' approach to addressing problems of labour's mal-treatment by capital, a more critical chain/network framework, rooted in an analysis of the labour process, represents a 'bottom-up' approach to these issues. The first perspective allocates labour a subordinate 'partnership' role to capital's profit orientation and states' attempts at regulating the capital-labour relation. The second perspective analytically prioritizes workers' struggles to ameliorate their conditions through collective action. ${ }^{139}$

136 Apple, Supplier Code of Conduct (2014) <https://www.apple.com/supplier-responsibility/ pdf/Apple_Supplier_Code_of_Conduct.pdf $>$ cited in Clarke and Boersma, above n 16, 115-6.

${ }^{137}$ Clarke and Boersma, above n 16, 115-6.

${ }^{138}$ Selwyn, 'Social Upgrading and Labour in Global Production Networks: A Critique and an Alternative Conception', above n 2, 87.

${ }^{139}$ Ibid 88 . 
Selwyn's alternative approach is much more likely to result in an emancipatory agenda than the top-down approach, which has enabled the lead companies in supply chains to retain their power and has resulted in weak disclosure provisions that have given little participatory opportunity to the affected stakeholders. In addition, if we change the terminology to refer to 'exploitation' or 'poverty' chains, this calls up the need for the lead companies as well as others who participate in the system as producers, consumers or facilitators, to accept responsibility in this global system.

\section{B Responsibility}

A number of models of responsibility are available to us. Thomas Pogge, for example, describes arrangements of this nature using a fault- or liability-based model and describes 'the institutions and social processes in which most of the world's people are embedded as a system that is imposed by some on others'. ${ }^{140}$ In Pogge's model there is a small global elite located in resource-rich developed countries who "enforce a global poverty regime under which [they] may claim the world's natural resources for [themselves] and can distribute these among [themselves] on mutually agreeable terms'. This global economic order is imposed on people in developing countries by Western governments acting in the name of their citizens, dominating those on whom it is imposed and driving them into deep poverty. ${ }^{141}$

Dahan, Lerner and Milman-Sivan broaden the cohort of those with responsibility by positing a set of five principles for allocating responsibility in the context of global chains of production. These are:

1. the principle of connectedness, grounded on special relationships that are based on shared identity or on participation in a joint activity;

2. the capacity principle, relating to the capacity of individuals or institutions to prevent and remedy unjust working conditions;

3. the beneficiary principle, relating to the economic gain that actors MNEs rather than subcontractors - derive from the labour connection and from production carried out under unjust conditions;

\footnotetext{
140 Thomas Pogge, World Poverty and Human Rights (Cambridge Polity Press, 2002) 142, discussed by Iris Marion Young, 'Responsibility and Global Labor Justice' (2004) 12 The Journal of Political Philosophy 365, 382.

${ }^{141}$ Ibid.
} 
4. the contribution principle, relating to conduct by individuals or institutions that is causally related to the unjust working conditions in question, such as the conduct of creating unjust labour conditions directly or indirectly, by actual actions or omissions;

5. the control principle, relating to the extent of control that an individual or institutional actor such as an MNE maintains over the unjust situation and over the conduct of participants such as sub-contractors who abuse workers' rights. ${ }^{142}$

Against this set of principles, it is easy to see that lead companies may have responsibility attributed to them, but so also would other participants in the system, including end consumers under the connectedness, beneficiary and contribution principles.

Young highlights the responsibility that arises from our social connections in global justice arrangements. The structural injustices inherent in poverty chains is a collective problem. Young presents a 'social connection model' of responsibility, according to which 'all agents who contribute by their actions to the structural processes that produce injustice have responsibilities to work to remedy these injustices'. ${ }^{143}$ Pointing to the example of sweatshops in global supply chains, Young observes that anti-sweatshop activists argue that the 'workers at the bottom of this system suffer injustice in the form of domination, coercion, and need-deprivation within a global system of vast inequalities'. ${ }^{144}$

Young sees this arrangement as a form of structural injustice in which social processes put large categories of persons under a systematic threat of domination or deprivation of the means to develop and exercise their capacities, whilst others may dominate or have a wide range of opportunities for developing and exercising their capacities. The injustice occurs as a consequence of many individuals and institutions acting in pursuit of their particular goals and interests, within given institutional rules and accepted norms. All participants in the ongoing schemes of cooperation that constitute these global structures are responsible for them, in the sense that they are part

\footnotetext{
${ }^{142}$ Yossi Dahan, Hanna Lerner and Faina Milman-Sivan, 'The Guiding Principles for Business and Human Rights: Labor Violations and Shared Responsibility' (2016) 32(4) International Journal of Comparative Labour Law and Industrial Relations 425, 436-75, acknowledging also Christian Barry, 'Global Justice: Aims, Arrangements, and Responsibilities' in Toni Erskine (ed), Can Institutions Have Responsibilities? (Palgrave, 2003) 218.

${ }^{143}$ Iris Marion Young, 'Responsibility and Global Justice: A Social Connection Model' (2006) 23(1) Social Philosophy and Policy 102, 102-3. See also Young, 'Responsibility and Global Labor Justice', above n 140, 102-3.

${ }^{144}$ Young, 'Responsibility and Global Justice: A Social Connection Model', above n 143, 111.
} 
of the process that produces unjust outcomes: ${ }^{145}$ 'We bear responsibility because we are part of the process. Within this scheme of social cooperation, each of us expects justice toward ourselves, and others can legitimately make claims on us. ${ }^{146}$ An example of the power of individuals is the potential of consumers and civil society organisations, acting collectively, to achieve social and economic change. Clarke and Boersma argue that 'pressure by civil society organisations harnessing consumer power is one of the driving forces behind changes in social and environmental practices' ${ }^{147}$ This gives rise, according to Young, to a political responsibility that is forward-looking and collective and demands us to change, through communication and discourse, the institutions and processes so that they generate less unjust outcomes. ${ }^{148}$

In this model workers share responsibility for combating exploitative conditions. This aspect makes the model emancipatory, in principle, because it demands that the workers be organised in order to participate in a transformative process. However, in reality, especially where freedom to organise is not recognised or not enforced, such workers may be able to discharge their responsibilities only with the support of others - often faraway and relatively privileged others - who make public the workers' grievances, put pressure on the agents that would block their unionisation, and provide material aid. ${ }^{149}$

Arguably, it is possible to adopt a mixed system of liability-based responsibility and collective social-connection responsibility. The liability-based responsibility would focus on the exploitative role played by lead corporations and the social-connection responsibility would focus on the roles of individuals and organisations that participate in ways that support the exploitation or leave it unhindered. The responsibility in both senses is to seek to eradicate the exploitation and to find systems that reduce or eliminate global inequality and poverty and protect against human rights abuses or unsafe work practices. ${ }^{150}$ The adoption of a mixed system of responsibility would demand a number of changes to the existing body of principles and standards. The UNGPs, for example, might be altered to reflect more accurately the moral responsibility of lead companies and MNEs/TNCs. Thus, they might be expressed not just in terms of a duty to respect human rights but positively, in terms of a duty to protect such rights, as states are required to do. The relevant corporations

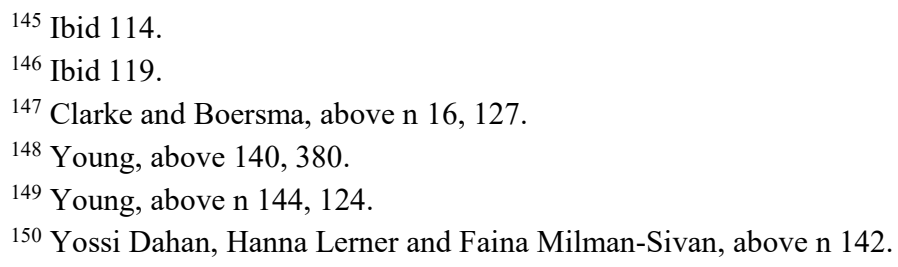


should also be given an express duty to protect and assist potential and actual victims of human rights abuses, remedying and compensating if abuses or violations occur. ${ }^{151}$ This duty could be shaped as a duty shared by all participants in the global production chains. ${ }^{152}$ This might require more coordinated disclosure provisions. As the BHRRC observes, 'the successful, but disparate, initiatives by governments ... if brought together, and applied internationally, would form a powerful global force to combat modern slavery'. ${ }^{153}$ The currently uncoordinated actions could

become a robust, and harmonised international standard for national legislations. Acting in concert, governments would have far greater impact on modern slavery and workers' rights and raise the floor of minimum corporate behaviour. Acting together, governments would also avoid a 'spaghetti soup' of incoherent legislations, and instead create the international predictability that global business seeks. ${ }^{154}$

Common regulation would 'allow better monitoring by workers, trade unions, NGOs and investors and, in case of non-compliance, targeted litigation'. ${ }^{155}$ It would allow those participants to make comparisons across companies more easily. ${ }^{156}$

\section{Responsibility, Participation and Disclosure}

A joint responsibility approach might also lead to more fundamental changes to the required disclosure process. The aim would be for disclosures to be: 1) steps towards prevention of labour exploitation or human rights abuses; 2) bases for dialogue between corporate actors and workers, consumers and their representatives and; 3) part of the apparatus for accountability and/or remediation. In order to produce such fundamental changes such disclosures would need to inform recipients (including all participants in the chain) of details of the whole chain's structure, the identity and contacts of all participant suppliers within the chain as well as their lead personnel, the contractual terms and conditions existing between relevant parties, the production processes across or throughout the chain, the terms and conditions of workers' contracts,

\footnotetext{
151 Ibid.

152 Alan Hyde, 'Legal Responsibility for Labour Conditions down the Production Chain' in Kamala Sankaran, Shae McCrystal and Judy Fudge (eds), Challenging the Legal Boundaries of Work Regulation (Hart Publishing, 2012) 83.

153 BHRRC, above n 25, 2.

154 Ibid 3.

155 Ibid 24.

${ }^{156}$ Chilton and Sarfaty, above n 1, 43-4.
} 
and the prices and wages paid at all levels. Details of policies should be made available to prevent or end human rights abuses, including forced labour, human trafficking and breaches of international conventions. Such details should show how the policies are being acted upon and the outcomes of such actions, including details of where problems of policy implementation may have arisen.

The disclosure and due diligence laws implemented in the UK and in France are important steps in this direction. This additional suggestion would require participants in all areas of the supply chain to be involved in the continuous updating and revision of the available information. External technological resources could be developed to enable this ongoing process. ${ }^{157}$

The potential for a meaningful and positive participation by consumer and worker/trade union networks is illustrated by the example provided by the Bangladesh Accord on Fire and Building Safety agreed in May 2013, (and recently renewed with effect from 1 June 2018). It was formulated in the wake of the Rana Plaza collapse. The Accord is an independent, legally binding agreement between the owners of signatory brands and trade unions designed to work towards a safe and healthy Bangladeshi Ready-Made Garment (RMG) Industry. The agreement consists of six key components: a five year legally binding agreement between the brand owners and trade unions to ensure a safe working environment in the Bangladeshi RMG industry; an independent inspection program supported by the brand owners in which workers and trade unions are involved; public disclosure of all factories, inspection reports and corrective action plans; a commitment by signatory brand owners to ensure that sufficient funds are available for remediation and to maintain sourcing relationships; democratically elected health and safety committees in all factories to identify and act on health and safety risks; and worker empowerment through an extensive training program, complaints mechanism and the right to refuse unsafe work. Importantly, the signatories to the Accord are required to assist in providing the supplier factories with the financial

\footnotetext{
${ }^{157}$ For example, Transparency One (see $<$ https://www.transparency-one.com/solution/>) is an agency that helps an organisation to map the entire supply chain by tracking compliance, and providing analytics to proactively manage business risks. This could simplify a complicated network with a complete set of dashboards that connects facilities with products, including indirect suppliers throughout every level. A participative disclosure system might well become possible under the blockchain technology. See further Cliff Moyce, How Blockchain Can Revolutionize Regulatory Compliance (10 August 2016) Corporate Compliance Insights $<\mathrm{http} / / / \mathrm{www}$.corporatecomplianceinsights.com/blockchain-regulatory-compliance $>$.
} 
resources necessary for maintaining safe workplaces and to carry out requisite structural repairs and safety improvements. ${ }^{158}$

The Accord has been described by commentators as a game changer ${ }^{159}$ and as a new paradigm for enforcing labour and human rights. ${ }^{160}$ It has great potential, and indeed its success - the overall progress rate of remediation at the 1620 Accord-covered factories is 85 per cent ${ }^{161}$ - has meant that its period of operation has been extended. Nevertheless, the Accord still has some limitations, such as its failure to lead to changes in buyer practice and also the fact that lead companies retain high leverage with regard to funding. ${ }^{162}$ Yet, despite these limitations, the Accord has been considered a major advance and its Steering Committee makes no bones about what has made it a successful agreement: the labour-corporate partnership at the heart of the agreement, the Accord's recognition of the need to ensure that factory owners are able to afford the cost of safety improvements, and the binding nature of the agreement. ${ }^{163}$ The Committee comments that

the Accord continues to be a unique opportunity for factory management, workers and their trade unions, global brands and global unions to combine their forces and thus remedy the systemic problem of building and fire safety deficits that has plagued the Bangladeshi garment industry. ${ }^{164}$

Similar to the Bangladeshi Accord, the negotiations currently under way to create a binding treaty governing the balance between business interests and human rights emphasise the participation of civil society representatives in that work. ${ }^{165}$ Whilst the ongoing work towards this binding treaty are beyond the scope of this article, it is worth noting that the current draft text includes

${ }^{158}$ Dahan, Lerner and Milman-Sivan, above n 142, 76.

159 Kate Conradt, Experts: Bangladesh Accord Is a Game Changer (12 September 2013) $<$ www.solidaritycenter.org/experts-bangladesh-accord-is-a-game-changer/>.

${ }^{160}$ Mark Anner, Jennifer Bair, Jeremy Blasi,'Toward Joint Liability in Global Supply Chains: Addressing the Root Causes of Labour Violations in International Subcontracting Networks' (2013) 35 Comparative Labour Law and Policy Journal 1, 2.

${ }^{161}$ Steering Committee, Bangladesh Accord, Statement Issued by the Steering Committee of the Accord (10 May 2018) Accord on Fire and Building Safety in Bangladesh $<$ http://bangladeshaccord.org/2018/05/statement-issued-steering-committee-accord/>.

${ }^{162}$ Christian Scheper, 'Labour Networks under Supply Chain Capitalism: The Politics of the Bangladesh Accord' (2013) 48 Development and Change 1069, 1081-2.

${ }^{163}$ Steering Committee, Bangladesh Accord, above n 161.

164 Ibid.

${ }^{165}$ Treaty on Transnational Corporations and Their Supply Chains with Regard to Human Rights Treaty Text Proposal, Global Campaign to Reclaim Peoples Sovereignty, Dismantle Corporate Power and Stop Impunity, October 2017 edition <https://www.stopcorporateimpunity. org/treaty-transnational-corporations-supply-chain-regard-human-rights/>. 
provisions that would recognise the participatory relevance of affected individuals and communities and their representatives.

Thus, draft clauses 28-35 of Part II contain commands for transnational corporations (TNCs) as follows:

28. TNCs shall respect the collective processes, associations, organisations, movements and other forms of representation communities as legitimate interlocutors for dialogue.

29. TNCs shall provide precise and detailed information to the public on: a. the purpose, nature, scale and terms of the leasing contracts for their operations and/or other contracts, as well as the terms of those contracts; $b$. the activities, structure, ownership and governance of the TNCs; c. the financial situation and performance of the TNCs; d. the availability of grievance and redress mechanisms and the procedures for their use.

30. TNCs shall make public the identity of the partners with whom their investors carry out business and/or financial activities in order to prevent tax fraud and evasion, or intra-firm capital flows that violate human rights.

31. TNCs shall make public their corporate management structures, the individuals who are responsible for making decisions and their respective responsibilities in the supply chain. By doing so, shareholders become liable and the corporate veil can be pierced whenever TNCs violate human rights.

32. TNCs shall disseminate information through all appropriate means (print, electronic and social media, including newspapers, radio, television, mailings, local meetings etc.), taking into account the situation of remote or isolated and non-literate communities, and ensure that notification and consultation are carried out in the language(s) of the affected individuals and communities.

33. TNCs shall publish adequate information on the conditions of employment of migrant workers throughout their supply chains.

34. TNCs shall be held liable for any adverse effects on human rights they cause or to which they contribute, through dissimulated activities and/or complicity, as well as through instigation or inducement. TNCs shall take adequate measures for the prevention, mitigation and, where appropriate, remediation of such adverse effects.

35. In the case of the possibility of risks deriving from their operations, TNCs shall guarantee the participation of the affected individuals or communities in the management of the situation, while ensuring collective representativeness. ... 


\section{Conclusions}

The way in which we conceptualise supply chains is important for the potential regulatory structure applied to them. Clearly, the history until now has been one of 'persistent corporate impunity'. ${ }^{166}$ Despite considerable progress with the introduction of multiple different initiatives, including development of due diligence procedures, serious problems remain. Businesses continue to violate human rights with little fear of punishment.

Ultimately, the main regulatory approach — disclosure - falls short of its goals of respecting human rights or furthering sustainable business behaviour. Due diligence has the potential to take regulation a step further forward, but it does not purport to lead to the eradication of human rights abuses. In this article I have followed Benjamin Selwyn's suggestion of renaming global supply chains 'global poverty chains' or 'global exploitation chains'. The use of such terminology highlights the normative requirements placed on lead firms and other participants in the production processes to take both collective and liability-based responsibility. The quest for transparency remains of central importance, but my suggested plan is to develop a more coordinated disclosure process that invites the participation of affected parties as well as the lead firms. New technologies open up these possibilities and could facilitate a regulatory structure that would also include enforcement procedures and remediation.

Ultimately, transparency is not by itself a sufficient regulatory strategy to remedy what are inherently exploitative arrangements. Transparency must be part of a more participatory system that empowers workers and enables them, with union representation, to ameliorate their conditions from the bottom up. The liability-based model suggested by Pogge therefore remains relevant. Lead firms, as well as states, must accept their responsibilities and compensate for human rights abuses that occur as a result of their exercise (and abuse) of power.

\footnotetext{
${ }^{166}$ Chip Pitts, Progress toward a Treaty on Business and Human Rights, Civicus State of Civil Society Report $2017<$ https://www.civicus.org/documents/reports-and-publications/SOCS/ 2017/essays/progress-toward-a-treaty-on-business-and-human-rights.pdf $>$.
} 